\title{
Hydraulically operated palm oil loader system design as fresh fruit bunch collector
}

\author{
S. Sarip ${ }^{1}$, M. A. Suhot ${ }^{2}$, H. M. Kaidi ${ }^{3}$, M. F. Mohd Noor ${ }^{4}$, S. Abdul Aziz ${ }^{5}$, N. A. Bani ${ }^{6}$, \\ M.S Noorazizi ${ }^{7}$ \\ 1,2,3,4,5,6,7 Department of Engineering and Technology, Razak Faculty of Technology and Informatics, \\ Universiti Teknologi Malaysia, Malaysia \\ ${ }^{1}$ Ocean Thermal Energy Centre, Universiti Teknologi Malaysia, Malaysia
}

\begin{tabular}{|c|c|}
\hline Article Info & ABSTRACT \\
\hline Article history: & \multirow{9}{*}{$\begin{array}{l}\text { Palm oil is one of the main agricultural contributors to Malaysia's Gross } \\
\text { Domestic Product (GDP). Although commercial palm oil plantations have } \\
\text { flourished in Malaysia for decades, there is still room for improvement } \\
\text { especially in minimizing manpower load and developing efficient machinery } \\
\text { to improve the various processes involved in the palm oil industry from estate } \\
\text { to the mills. This paper presents a modified towable backhoe to assist in the } \\
\text { Fresh Fruit Bunch (FFB) collecting process as an effort to save time. The main } \\
\text { objective of this study is to design a machine that can be used by smallholders } \\
\text { of oil palm in order to help speed up the work process. With a boom extension } \\
\text { and an innovative grabber, the pressure needed to operate the hydraulic system } \\
\text { was analyzed to ensure the towable backhoe functioned effectively and } \\
\text { fulfilled its objectives. From the calculations done, the maximum pressure that } \\
\text { the system can supply is } 31.28 \mathrm{MPa} \text { which is higher than the } 11 \mathrm{MPa} \text { minimum } \\
\text { reguired for the hydraulic system to operate. }\end{array}$} \\
\hline Received Mar 26, 2019 & \\
\hline Revised May 28, 2019 & \\
\hline Accepted Jun 17, 2019 & \\
\hline Keywords: & \\
\hline Fresh fruit bunch & \\
\hline Hydraulic & \\
\hline Mechanical grabber & \\
\hline Palm oil & \\
\hline
\end{tabular}

Copyright $(2020$ Institute of Advanced Engineering and Science. All rights reserved.

\section{Corresponding Author:}

Shamsul Sarip,

Engineering and Technology,

Razak Faculty of Technology and Informatics,

Universiti Teknologi Malaysia, Jalan Sultan Yahya Petra, 54100 Kuala Lumpur, Malaysia.

Email: shamsuls.kl@utm.my

\section{INTRODUCTION}

Palm oil industry in Malaysia is one of main contributors of agricultural income in Malaysia. According to the Malaysian Department of Statistics, in 2016, the production of fresh fruit bunch (FFB) from the palm oil industry contributed RM38.5 billion to the overall Gross Domestic Product (GDP) of Malaysia [1]. The palm oil industry consists of the processes of planting, farm management, harvesting and processing before the final product, palm oil, is produced at the mill. The management and harvesting processes have been identified as requiring more manpower compared to the other processes. Harnessing the latest technology and through the use of creative innovations, some of the manual work has been automated and less manpower is needed.

According to Shuib et al., [2], FFB collection was placed fourth in terms of total workforce required in the palm oil cultivation process in Malaysia in 2008. The study also highlighted some innovations that have been developed in order to assist in the harvesting and collecting of fresh fruit bunch before delivery to the mills. These included using a mechanical approach and modification of the terrain. As reported by Pebrian et al., [3], the energy expenditure per man worker is $48.49 \mathrm{kcal} / \mathrm{hour} / \mathrm{man}$ during the holing process stage before FFB is transported to the mill.

As reported by the Malaysian Palm Oil Board (MPOB), various innovations designed specifically to improvise and minimize manpower usage in harvesting and collecting FFB before transportion to the palm oil 
mill. This was highlighted by Azwan and Setiawan [4-5], who listed some of the innovations to reduce manpower in palm oil processing activities. This has been supported by Shuib and Muhammad [2, 6-7] who stated that from 1987 to 2017, there were 45 innovations purpose-built for palm oil activities registered with the MPOB. Involvement from higher learning institutions also contributed to the development of new technology for the palm oil industry such as by Wan Ishak [8] who developed the Oil Palm Harvester Robot at the Universiti Putra Malaysia. Darius and his team [3] who developed the 4 wheel drive prime mover along with an attachment to reduce manpower usage in palm oil estate activities. This paper focuses on the design and fabrication of a hydraulically operated palm oil loader for FFB collecting process with the main objective of reducing the manpower required for FFB collecting activities.

In order to improve the FFB collecting process, an innovation using a hydraulic grabber on a mini excavator was developed. The objective of the development of this product was to minimize the workforce used and to reduce the manual processes in FFB collecting especially in palm oil plantations located in peat soil areas. The machine will focus on the collection of harvested FFB near the collector truck terrain. By employing a fluid power system, the FFB collector has been able to minimize manpower needs during the collection process by towing the FFB collector at the back of the collector truck. Apart from that, the towable backhoe design was focused on the ability to operate on peat soil. Peat soil contains high amounts of water which causes problems when activities are carried out on top of this type of soil. This is due to the soil's low shear strength and high permeability as described by Ramesh and Adnan [9-10]. The higher water content in peat soil causes the soil to become soft, thus making it problematic when applying a heavy load on top or within it. Several factors were taken into consideration during the design process of a hydraulic grabber for FFB collection. These include an innovative design of towable backhoe with a grabber mechanism for collecting FFB and towed by a truck to the next process.

\section{RESEARCH METHOD}

Design specifications for the hydraulic grabber were made related to the capabilities of the product and its technical specifications. For this study, the technical specifications of agriculture towable backhoes before modification, and the requirements to fulfil the main objective of this project were identified. Requirements of the project were identified based on a survey and site visit to the towable backhoes involved in the harvesting and collecting of FFB, and from literature review [11-14]. The results obtained were filtered and the requirements from the survey were then prioritized as shown in Table 1 . The specifications and capabilities of the towable backhoe are listed below in Table 2.

Table 1. The Requirements Specified by the Towable Backhoes based on the Survey and Site Visit

\begin{tabular}{cl}
\hline Criteria & \multicolumn{1}{c}{ Description } \\
\hline Load & Able to grab and move a minimum of $10 \mathrm{FFB}$ at a time \\
Rotation & Able to collect FFB on the right and left side of the truck path \\
Height & Able to lift up to 2.5m height from the ground \\
Terrain & Able to operate on peat soil and can be towed by a truck. \\
\hline
\end{tabular}

Table 2. Specifications of the Hydraulic System and Power Source for A Hydraulically Operated Palm Oil Loader

\begin{tabular}{ll}
\hline Parameter & Description \\
\hline Power source & ICE \\
Model & $\mathrm{JF} 270$ \\
Engine capacity & $270 \mathrm{cc}$ \\
Maximum Output Power of ICE $(\mathrm{kW})$ & 5.2 \\
Maximum RPM & 3600 \\
Pump Type & External Gear Pump \\
Volumetric displacement, $\mathrm{V}_{\mathrm{D}}$ & $0.00000277 \mathrm{~m}^{3}$ \\
Maximum pumping pressure & $31.28 \mathrm{MPa} @ 3600 \mathrm{RPM}$ \\
Calculated Minimum Pressure requirement & $11 \mathrm{MPa}$ \\
Excessive Pressure $(\%)$ & $64.8 @ 3600 \mathrm{RPM}$ \\
Piston Diameter, $\mathrm{D}_{\mathrm{P}}$ & $68 \mathrm{~mm}$ \\
Rod Diameter, $\mathrm{D}_{\mathrm{R}}$ & $35 \mathrm{~mm}$ \\
Maximum angle $\theta_{4}$ for boom cylinder (Cylinder 1) in retraction stroke & $15^{\circ}$ \\
Maximum angle $\theta_{3}$ for arm 2 cylinder (Cylinder 3$)$ in retraction stroke & $14.5^{\circ}$ \\
Pitching angle of Arm $1, \theta_{1}$ during lifting. & $45^{\circ}$ \\
Turning angle of stick & $149.5^{\circ}$ \\
Swing angle of boom & $140^{\circ}$ \\
Weight FFB $(10$ bunches) & $200 \mathrm{~kg}$ \\
Weight of arm $1, \mathrm{~m}_{1}$ & $69.5 \mathrm{~kg}$ \\
Weight of arm $2, \mathrm{~m}_{2}$ & $50 \mathrm{~kg}$ \\
\hline
\end{tabular}


For this innovation, a mathematical model was used to analyze the capabilities of the grabber with a maximum load, and the maximum load that could be retained by each of the cylinders. Once the maximum capabilities were determined for each cylinder, then the fabrication could take place. For the solutions and mathematical models used in the design and fabrication process as refer to [15-18].

\section{RESULTS AND ANALYSIS}

From the design requirements and technical specifications listed, the design of a hydraulic powered system FFB Grabber was developed. The schematic diagram of the hydraulic system for the hydraulic grabber has been designed as a reference model before the development of the mathematical models [19-21]. The schematic diagram that was designed is shown in Figure 1.

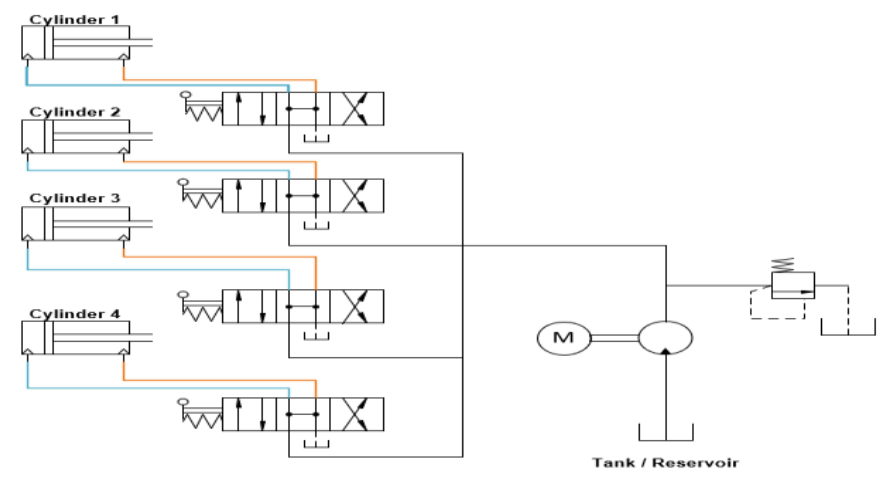

Figure 1. The schematic diagram of a hydraulic grabber for FFB collection

Figure 1 depicts a total of 4 cylinders in which each cylinder has its own function. Each cylinder is connected to the valve with a manual spring level as a controller for the hydraulic system and is connected to the tank located within the chassis of the towable backhoe. The lever position and function of each lever together with the cylinders' action are listed in Table 3 below. There are two levers with Lever No. 1 controlling the grabber and lower arm function while Lever No. 2 controls the upper arm and arm swing.

Table 3. Operations and functions of the Hydraulically Operated Palm Oil Loader

\begin{tabular}{|c|c|c|c|c|}
\hline Operation & Boom Cylinder & Stick Cylinder & Grabber Cylinder & $\begin{array}{l}\text { Boom Swing } \\
\text { Cylinder }\end{array}$ \\
\hline Lowering both arm $1 \& 2$ & $\begin{array}{l}\text { Piston in expansion } \\
\text { and hold pressure }\end{array}$ & $\begin{array}{l}\text { Piston in expansion } \\
\text { and hold pressure }\end{array}$ & hold pressure & No pressure \\
\hline Opening grabber & hold pressure & hold pressure & $\begin{array}{l}\text { Piston in Expansion until } \\
\text { widely open }\end{array}$ & No pressure \\
\hline Closing grabber & hold pressure & hold pressure & $\begin{array}{l}\text { Piston extraction until end } \\
\text { base and hold pressure }\end{array}$ & No pressure \\
\hline $\begin{array}{l}\text { Lifting both arm } 1 \& 2 \text { at higher } \\
\text { than open cabin of lorry }\end{array}$ & $\begin{array}{l}\text { extraction and hold } \\
\text { pressure }\end{array}$ & $\begin{array}{l}\text { extraction and hold } \\
\text { pressure }\end{array}$ & hold pressure & No pressure \\
\hline $\begin{array}{c}\text { Swing both arm } 1 \& 2 \text { to the right } \\
\text { at upper of cabin }\end{array}$ & hold pressure & hold pressure & hold pressure & $\begin{array}{l}\text { Piston in } \\
\text { Expansion }\end{array}$ \\
\hline $\begin{array}{c}\text { Swing both arm } 1 \& 2 \text { to the left at } \\
\text { upper of cabin }\end{array}$ & hold pressure & hold pressure & hold pressure & $\begin{array}{l}\text { Piston in } \\
\text { retraction }\end{array}$ \\
\hline
\end{tabular}

\subsection{Calculations on the Capacities of the Cylinders}

Table 2 shows the specifications and maximum achieved by the pressurized hydraulic pump in the palm oil loader during the lifting of both arms 1 and 2 at a height higher than the open cabin of a lorry and during the swinging of both arms 1 and 2 to the left or right above the cabin. This study only considered the effects of arm 1 and arm 2 movements with the existing load to reach the maximum operational figures of the hydraulically operated palm oil loader to pick and place the FFB into the cabin as shown in Figure 2. Assigning the stick Cylinder as Cylinder 3 in Figure 2, then F3 as maximum load during the piston retraction stroke as the function of axis $\mathrm{x}$ '. This assumes the origin $\mathrm{O} 2$ has a pin joint for a complete free body diagram of arm 2 in the schematic. The parameter of force is depicted in Table 4. 


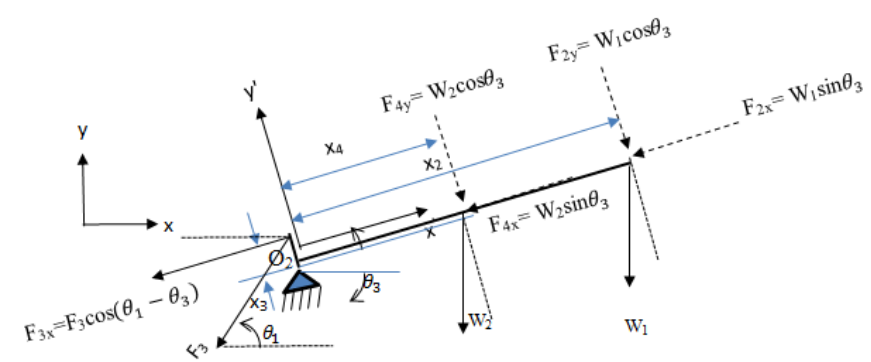

Figure 2. Schematic diagram for load acting on arm 2 with the pin joint at origin $\mathrm{O} 2$

Table 4. Parameter and Value of Force Acting on Arm 2 (Stick Arm)

\begin{tabular}{lc}
\hline Parameter & Value \\
\hline Mass of $\operatorname{arm} 2, \mathrm{~m}_{2}$ & $50 \mathrm{~kg}$ \\
Mass of grabber, $\mathrm{m}_{\mathrm{g}}$ & $50 \mathrm{~kg}$ \\
Mass of FFB $(10$ bunches $), \mathrm{m}_{\mathrm{ffb} 10}$ & $200 \mathrm{~kg}$ \\
$\mathrm{~W}_{1}=\left(\mathrm{m}_{\mathrm{g}}+\mathrm{m}_{\mathrm{ffb} 10}\right) \mathrm{g}$ & $2452.5 \mathrm{~N}$ \\
$\mathrm{~W}_{2}=\mathrm{m}_{2} \mathrm{~g}$ & $490.5 \mathrm{~N}$ \\
$\mathrm{x}_{2}$ & $2.06 \mathrm{~m}$ \\
$\mathrm{X}_{3}$ & $0.215 \mathrm{~m}$ \\
$\mathrm{x}_{4} \mathrm{x}_{2} / 2$ & $1.03 \mathrm{~m}$ \\
$\theta_{3}$ as fixed value & $14.5^{\circ}$ \\
$\theta_{1}$ as variable value. & $45^{\circ}, 50^{\circ}, 60^{\circ}$ \\
\hline
\end{tabular}

By using moment equilibrium at $\mathrm{Z}$ axis in (1), when normalized to $\mathrm{x}^{\prime} \mathrm{y}$ ' axis [12]:

$$
\sum M_{01}: F_{3 x} x_{3}=F_{2 y} x_{2}+F_{4 y} x_{4}
$$

We get the normal force acting on piston at cylinder 3, F3 as follows,

$$
\mathrm{F} 3=\frac{\left(W_{1} \cos \theta_{3}\right) x_{2}+\left(W_{2} \cos \theta_{3}\right) x_{4}}{x_{3} \cos \left(\theta_{1}-\theta_{3}\right)}
$$

To determine the minimum pressure for the retraction stroke for Cylinder 3; if the designed diameter size of piston, DP, and rod, DR, are fixed at $68 \mathrm{~mm}$ and $35 \mathrm{~mm}$ respectively.

$$
\begin{aligned}
& \text { PRET3 }=\frac{F_{3}}{A_{P}-A_{R}} \\
& =\frac{F_{3}}{\frac{\pi}{4}\left(0.068^{2}-0.035^{2}\right) m^{2}}=\frac{F_{3}}{0.00266957 m^{2}}
\end{aligned}
$$

If $\theta_{3}=14.5^{\circ}$ is fixed, then (3) becomes the formula for the minimum pressure required for the retraction stroke for Cylinder 3. Table 5 depicts the results for the different variables of pitching angle $\theta_{1}=45^{\circ}$, $50^{\circ}, 60^{\circ}$. The calculations were performed using Microsoft Excel to compute the respective results using a fixed input and different variables to determine the angle effects in the design of the pumping effort, and to determine the minimum pressure required to accomplish the overall operations as depicted in Table 1. The value of normal force and pressure retraction stroke increased in the range of $29043.24 \mathrm{~N}$ to $35702.17 \mathrm{~N}$ and $10.88 \mathrm{MPa}$ to $13.37 \mathrm{MPa}$ respectively.

Table 5. Results for Different Variables of Pitching Angle $\Theta \_1=45^{\circ}, 50^{\circ}, 60^{\circ}$

\begin{tabular}{cccc}
\hline Parameters & \multicolumn{3}{c}{ Pitching angle of Arm 1 (Boom), $\theta_{1}$} \\
\cline { 2 - 4 } & $45^{\circ}$ & $50^{\circ}$ & $60^{\circ}$ \\
Normal force acting on piston at cylinder 3, $\mathrm{F}_{3}(\mathrm{~N})$ & 29043.24 & 30737.81 & 35702.17 \\
Equivalent mass, $\mathrm{m}_{\mathrm{e}}(\mathrm{kg})$ & $2,960.55$ & $3,133.3$ & 3,639 \\
Effective area, & 0.00266957 & 0.00266957 & 0.00266957 \\
$A_{P}-A_{R}\left(\mathrm{~m}^{2}\right)$ & 10.88 & 11.51 & 13.37 \\
Pressure, $\mathrm{P}_{\mathrm{RET}}(\mathrm{MPa})$ & &
\end{tabular}


Cylinder 1 as boom Cylinder shown in Figure 1, then F1 is maximum load during piston retraction as the function of axis X' as shown in the free body diagram of arm 1 and 2 as shown in Figure 3. Origin O1 has a pin joint for overall reacting force on the free body diagram of arms. The Cylinder 3 was in a pressurized condition to hold the arm 2 as a solid frame. The parameters of forces are depicted in Table 6.

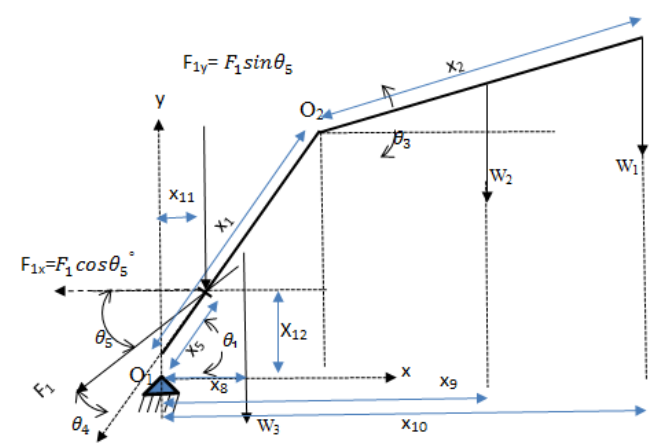

Figure 3. Schematic of free body diagram for arm 1 with the pin joint at origin $\mathrm{O} 1$ and $\mathrm{O} 2$

Table 6. Parameter and Value of Force Acting on Arm 1 (Boom Arm)

\begin{tabular}{cc}
\hline Parameters & Values \\
\hline Mass of arm $1, \mathrm{~m}_{1}$ & $62.5 \mathrm{~kg}$ \\
Mass of cylinder 3 and cylinder $1, \mathrm{~m}_{\mathrm{c} 3}=\mathrm{m}_{\mathrm{cl}}$ & $3.5 \mathrm{~kg}$ (approximately) \\
$\mathrm{M}_{\mathrm{T} 1}=\mathrm{m}_{1}+\mathrm{m}_{\mathrm{c} 3}+\mathrm{m}_{\mathrm{cl}}$ & $69.5 \mathrm{~kg}$ \\
$\mathrm{~W}_{3}=\mathrm{m}_{\mathrm{T} 1} \mathrm{~g}$ & $681.8 \mathrm{~N}$ \\
$\mathrm{x}_{1}$ & $1.92 \mathrm{~m}$ \\
$\mathrm{x}_{2}$ & $2.06 \mathrm{~m}$ \\
$\mathrm{x}_{4}=\mathrm{X}_{2} / 2$ & $1.03 \mathrm{~m}$ \\
$\mathrm{x}_{5}$ & $0.74 \mathrm{~m}$ \\
$\mathrm{x}_{6}=\mathrm{x}_{1} / 2$ & $0.96 \mathrm{~m}$ \\
$\mathrm{x}_{7}$ & $0.13 \mathrm{~m}$ \\
$\theta_{3}$ as fixed value. & $14.5^{\circ}$ \\
$\theta_{4}$ as fixed value. & $15^{\circ}$ \\
$\theta_{5}$ as variable value. & $\theta_{1}-\theta_{4}$ \\
$\theta_{1}$ as variable value. & $45^{\circ}, 50^{\circ}, 60^{\circ}$ \\
\hline
\end{tabular}

By using moment equilibrium $\mathrm{Z}$ axis in (4) at the point when all reacting forces are as shown in Figure 4, we can compute:

$$
\begin{aligned}
& \sum M_{z 2}: F_{1 x} x_{9}-F_{1 y} x_{11}=W_{1} x_{10}+W_{2} x_{9}+W_{3} x_{8} \\
& \left(F_{1} \cos \theta_{5}\right) x_{9}-\left(F_{1} \sin \theta_{5}\right) x_{11}=W_{1} x_{10}+W_{2} x_{9}+W_{3} x_{8}
\end{aligned}
$$

Force acting on cylinder 1 is,

$\mathrm{F} 1=\frac{W_{1} x_{10}+W_{2} x_{9}+W_{3} x_{8}}{\left(\cos \theta_{5}\right) x_{9}-\left(\sin \theta_{5}\right) x_{11}}$

To determine the minimum pressure for the retraction stroke for Cylinder 1 , the designed diameter size of piston, DP, and rod, DR, are fixed at $68 \mathrm{~mm}$ and $35 \mathrm{~mm}$ respectively.

$$
\begin{aligned}
& \text { PRET } 1=\frac{F_{1}}{A_{P}-A_{R}} \\
& =\frac{F_{1}}{\frac{\pi}{4}\left(0.068^{2}-0.035^{2}\right) m^{2}}=\frac{F_{1}}{0.00266957 \mathrm{~m}^{2}}
\end{aligned}
$$

If $\theta_{4}=15^{\circ}$ is fixed, then (6) becomes the formula for minimum pressure required for the retraction stroke for Cylinder 3. Table 7 depicts the results for the different variables of pitching angle $\theta_{1}=45^{\circ}, 50^{\circ}, 60^{\circ}$. The calculations to compute the respective results using fixed input and different variables to determine the 
effect of angle in the design of pumping effort, with the minimum pressure required to accomplish overall operations as depicted in Table 1. According to Table 7, the value of normal force and pressure retraction stroke is in the range of $26,956.8 \mathrm{~N}$ to $72,563.98 \mathrm{~N}$ and $10.1 \mathrm{MPa}$ to $27.18 \mathrm{MPa}$ respectively.

Table 7. Results for Different Variables of Pitching Angle $\theta_{1}=45^{\circ}, 50^{\circ}, 60^{\circ}$

\begin{tabular}{cccc}
\hline Parameters & \multicolumn{3}{c}{ Pitching angle of Arm 1 (Boom), $\theta_{1}$} \\
\cline { 2 - 4 } & $45^{\circ}$ & $50^{\circ}$ & $60^{\circ}$ \\
Normal force acting on piston at cylinder 1, $\mathrm{F}_{1}(\mathrm{~N})$ & $31,050.38$ & $72,563.98$ & $26,956.8$ \\
Equivalent mass, $\mathrm{m}_{\mathrm{e}}(\mathrm{kg})$ & $3,165.18$ & $7,396.94$ & $2,747.9$ \\
Effective area, & 0.00266957 & 0.00266957 & 0.00266957 \\
$A_{P}-A_{R}\left(\mathrm{~m}^{2}\right)$ & 11.63 & 27.18 & 10.1 \\
\hline Pressure, $\mathrm{P}_{\mathrm{RET}}(\mathrm{MPa})$ & & & \\
\hline
\end{tabular}

The trend of the graphs as shown in Figure 5 confirmed the effect of angle on gravity on arm 1 and arm 2. The horizontal line shows the pressure and normal force in cylinder 3 which depicts an increasing value without any gravity effects compared to the situation for cylinder 1 . The weight distribution due to higher center of gravity causes the vertical structure to have better and smoother handling in terms of hydraulic pressure capability and produce lower energy consumption. While the horizontal structure with a higher theta angle need more space heavier and more energy needed in terms of hydraulic pressure requirements. However, the pressure in cylinder 1 shows the dramatic increase of the overall pressure to a maximum of $27.18 \mathrm{MPa}$ in order to stabilize the overall structural frame of the Hydraulically Operated Palm Oil Loader. Then it reduces to $10.1 \mathrm{MPa}$ with a reduction in energy consumption from less pumping effort required by the petrol-fueled Internal Combustion Engine (ICE) with $5.2 \mathrm{~kW}$ output power at a maximum of $3600 \mathrm{RPM}$ as mentioned in Table 2.

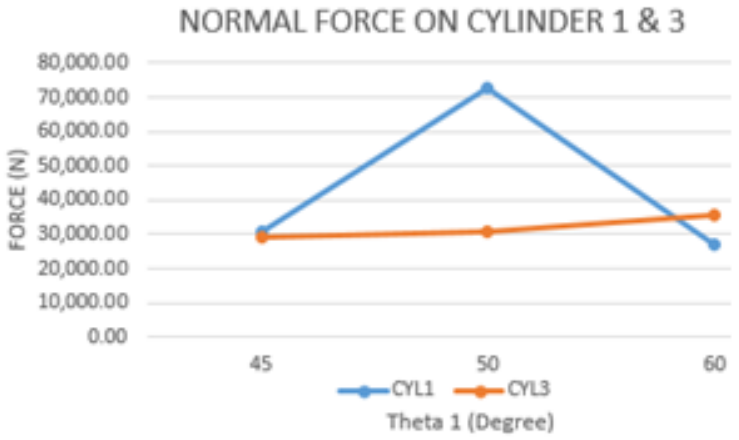

Figure 4. Normal force cylinder $1 \& 3$ vs theta 1
PRESSURE OF CYLINDER 1\&3 VERSUS THETA1

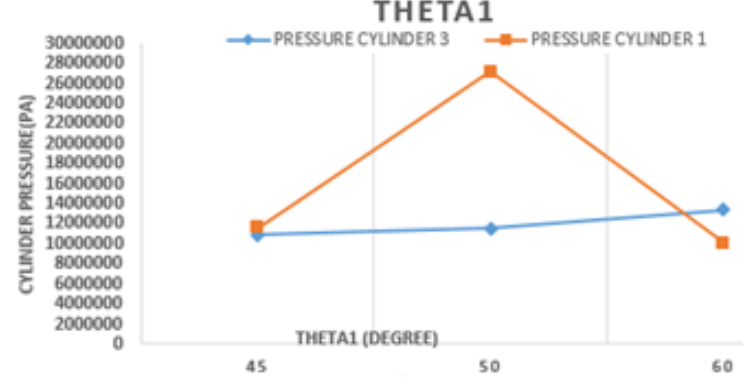

Figure 5. Pressure of cylinder $1 \& 3$ vs theta 1

The pump needs to support the minimum pressure requirements of the palm oil loader, and the specification of the hydraulic system and power source as detailed in Table 6. The preferred pump type is an external gear pump as it is able to provide the overall efficiency, $\eta_{O}$, of about $80-90 \%$ [22-25]. In order to verify the capabilities of the selected pump, the basic formulations are shown below: -

The pump volumetric displacement, VD.

$$
\begin{aligned}
& V_{D}=\frac{\pi}{4}\left(D_{O}{ }^{2}-D_{i}{ }^{2}\right) L \\
& =\frac{\pi}{4}\left(0.068^{2}-0.035^{2}\right) 0.008=0.00000277 \mathrm{~m} 3
\end{aligned}
$$

Then, pump flow rate, QT.

$$
\text { QT }=\text { VDN }
$$

$=0.00000277 \mathrm{~m} 3 \frac{3600}{60}=0.000166 \mathrm{~m} 3 \mathrm{~s}-1$

Actual flow rate, QA in (9), volumetric efficiency, $\eta_{V}=0.8$ 
$\eta_{V}=\frac{Q_{A}}{Q_{T}}$

$\mathrm{QA}=\eta_{V} Q_{T}=0.8(0.000166 \mathrm{~m} 3 \mathrm{~s}-1)=0.000133 \mathrm{~m} 3 \mathrm{~s}-1$

Power output of the Internal Combustion Engine (ICE), PO(ICE) is equal to Power input to Gear pump, $\mathrm{Pi}$; hence input power of pump, $\mathrm{PI}(\mathrm{PUMP})=\mathrm{PO}(\mathrm{ICE})=5.2 \mathrm{~kW}$.

Since the given power output of ICE $=5.2 \mathrm{~kW}$, overall efficiency of pump, $\eta_{O}$,

$$
\eta_{O}=\frac{P_{O}}{P_{I}}
$$

$\mathrm{PO}(\mathrm{PUM})=\eta_{O} P_{I}=0.8(5.2 \mathrm{~kW})=4.16 \mathrm{~kW}=\mathrm{QAp}$, then

$\mathrm{p}=\frac{4.16 \mathrm{~kW}}{0.000133 \mathrm{~m} 3 \mathrm{~s}-1}=31,278,195 \mathrm{~Pa}=31.28 \mathrm{MPa}$.

Therefore, the maximum pressure produced by the selected gear pump is $31.28 \mathrm{MPa}$ which is higher than the 27.18 MPa minimum required for the designed hydraulic specification as shown in Table 6 . Using the selected gear pump provides excessive pressure available of about $13.1 \%$ to allow the remaining pressure to be used for cylinder 4 for a maximum angle of $140^{\circ}$ in swinging the boom.

\section{CONCLUSION}

Through the mathematical method, the maximum pressure that the towable backhoe can withstand is $31.28 \mathrm{MPa}$ which is more than the required $27.18 \mathrm{MPa}$. The variation of $\theta_{1}=45^{\circ}, 50^{\circ}, 60^{\circ}$ with a fixed value of Maximum angle $\theta_{4}=15^{\circ}$ for boom cylinder (Cylinder 1 ) and Maximum angle $\theta_{3}=14.5^{\circ}$ for arm 2 cylinder (Cylinder 3 ) in retraction stroke were studied to determine the overall pumping effort used to overcome the moment effect where the fixed angle of frame is needed to optimize the minimum pressure required. The gear pump with a maximum pumping pressure of $31.28 \mathrm{MPa}$ or $3600 \mathrm{RPM}$ is acceptable for the Hydraulically Operated Palm Oil Loader for the minimum pressure requirements for all $\theta_{1}=45^{\circ}, 50^{\circ}, 60^{\circ}$.

\section{ACKNOWLEDGEMENTS}

This work is supported by Universiti Teknologi Malaysia under Research University Grant Q.K130000.3556.07G32 and Q.K130000.2540.17H58 for the financial support provided throughout the course of this research project.

\section{REFERENCES}

[1] Nurhidayu. A, et al., "The Production of Crude Palm Oil in Malaysia," Int. Journal of Economics and Management 11 (S3) : 591-606 (2017)

[2] A. R. Shuib, M. Ramdhan, and M. S. Deraman, "Enhancing Field Mechanization in Oil Palm Management," Oil Palm Bull., vol. 61, no. November, pp. 1-10, 2010..

[3] D. El Pebrian, A. Yahya, T. A. Ishola, S. M. Roodi, and H. Hasan, "Oil Palm Plantation Mechanisation in Totality," Int. Conf. Agric. Food Eng. Life (Cafei 2012), no. November, pp. 739-751, 2012.

[4] M. Azwan M. Bakri, Norman Kamaruddin, Abd Rahim Shuib, Norasikin A. Ludin, "Sustainable Development on Oil Palm Mechanisation," July 2018.

[5] A. W. Setiawan et al., "Classification of Palm Oil Fresh Fruit Bunch using Multiband Optical Sensors," International Journal of Electrical and Computer Engineering (IJECE) Vol 9, No 4: August 2019 (Part I).

[6] Z. Muhammad and Aziz, "Mechanization in Oil Palm Harvesting," International Journal of Academic Research in Business and Social Sciences, 8(5), 247-256.

[7] Azali Awaludin, et al., "Performance Study of an Oil Palm Fresh Fruit Bunch Three Wheeler Evacuation Machine," The Online Journal of Science and Technology, Volume 5, Issue, 2015.

[8] W. I. Wan Ismail, et al., "Research and Development of Oil Palm Harvester Robot At Universiti Putra Malaysia," Int. J. Eng. Technol., vol. 7, no. 2, pp. 87-94, 2010.

[9] Ramesh Veloo, Jaai Haron and Zainudin Mohd Yatim, "Economic of Mechanisation- Estate Experience," 4th National Seminar On Oil Palm Mechanization, PalmMech 2010, page 227-246, Kuala Lumpur

[10] Zainorabidin, Adnan, Mohamad, and H. Musa, "Engineering Properties of Integrated Tropical Peat Soil in Malaysia," J. Geotech. Eng., vol. 22, pp. 1-9, 2017.

[11] M. Fargnoli et al., "Design For Safety In Agricultural Machinery," International Design Conference-Design 2010 Dubrovnik-Croatia, May 17 - 20, 2010.

[12] Mutasim El Ta Yeb Ali. "Design And Development of an Integrated Infield Collection-Transportation Machine for Oil Palm Fresh Fruit Bunch”. PhD Thesis. Serdang. Universiti Putra Malaysia. 2002. 
[13] Azmi Yahya. "Mechanised Oil Palm Fresh Fruit Bunch Infield Collection-Transportation System". Universiti Putra Malaysia. UPM Research Report 1997-2000, Section 2-Extended Abstracts. Agricultural Sciences. Pp. 80-81.

[14] Yong Kian Keong, "Site yield potential of Felda Global Ventures Plantation Malaysian", Mini R \& D Seminar, Kuala Lumpur. 2013.

[15] A. Esposito, "Fluid Power With Applications", Fourth Edi. New Jersey: PRENTICE HALL, 1997.

[16] D. H Yacob, et al., "Critical Design Factors on Performance of Car Jack Lifting Operations," Indonesian Journal of Electrical Engineering and Computer Science (IJEECS), vol.2, pp. 513-520, 2018.

[17] S. Sarip, et al., "Hybrid Renewable Energy Power System Model Based on Electrification Requirements of One Fathom Bank Malaysia," Indonesian Journal of Electrical Engineering and Computer Science (IJEECS), vol 2, pp. 513-520. 2018.

[18] Deraman, M. S. (Jun, 2013). "Rhyno : A Multiporpose Wheel Type Transporter For Oil Palm Activities On Undulating Terrain And Soggy Areas". Kuala Lumpur, Malaysia: Malaysia Palm Oil Board, Ministry of Plantation Industries and Commodities, Malaysia.

[19] Jelani, A. B. (2008). "CANTAS TM-A Tool For The Efficient Harvesting Of Oil Palm Fresh Fruit Bunches”. Journal of Oil Palm Research, 548-558.

[20] Mizou Holdings Sdn Bhd. (2016)." Agricultural Equipment”. Retrieved from mizou: http://www.mizou.com.my/rhyno-w700.html.

[21] P.D Turner, R.A. Gillbanks. (2003). "Oil Palm Cultivation and Management”. Kuala Lumpur: The Incorporated Society of Planters.

[22] Turner, P. D., \& Gillbanks, R. A. (1974). "Oil palm cultivation and management". Oil palm cultivation and management.

[23] Agrowing.co.id. (2017). FASTREX CT-02. Retrieved from agrowing: https://agrowing.co.id/AgriBisnis/fastrex-ct-02/.

[24] Azmi Yahya. "Design and Development of an All-Terrain Crop Upkeep and Fresh Fruit BunchCollectionTransportation Machine System for Oil Palm Plantation”. Universiti Putra Malaysia. Agricultural Sciences 2004.

[25] D. E. Pebrian and Azmi Yahya. "Design and Development of a Prototype Trailed Type Oil Palm Seedling Transplanter”. Journal Oil Palm Research. 15(1): 32-40. 2003.

\section{BIOGRAPHIES OF AUTHORS}
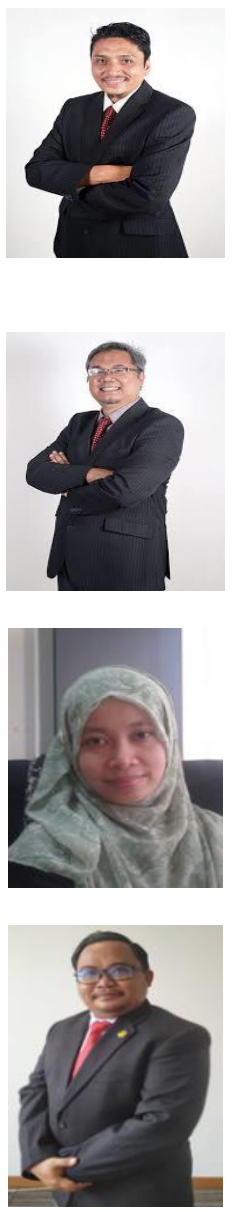

Shamsul Sarip is an academic staff of Razak Faculty of Technology and Informatics, Universiti Teknologi Malaysia Kuala Lumpur. He received Diploma of Mechanical Engineering in 1995, Bachelor of Mechanical Engineering in 1998, and Master of Mechanical Engineering in 2002 from the Universiti Teknologi Malaysia. He then obtained his $\mathrm{PhD}$ in Mechanical Engineering from University of Bradford, United Kingdom in 2012. He has been involved in the area of engineering design including lightweight disc brake, micro hydro turbine, ram pump, marine current turbine and product development. He also involved in university motor sport activities which required him to expand the knowledge to finite element analysis, heat transfer, CFD and structure analysis.

Mohamed Azlan Suhot is an academic staff of Faculty of Technology and Informatics Razak, UTM Kuala Lumpur. He received his bachelor and masters education in Materials Engineering from University Science Malaysia in 1996 and 2000 respectively. He then pursued and finished his PhD in Composite Materials from University of Southampton, United Kingdom in 2008. He has been involved in the area of renewable energy especially involving installation of sustainable pumps and turbines in remote and rural area. He is also very passionate in activities involving UTM students which also required him to be close with communities and NGOs.

Hazilah Mad Kaidi received her B.Eng (Horns) in Electrical Engineering in Teleommunication, Universiti Teknologi Malaysia, the M.Sc. degree in Telecommunication and Information Engineering at Universiti Teknologi MARA and the Ph.D. degree from the Universiti Teknologi Malaysia. She is currently a senior lecturer at Razak Faculty of Technology and Informatics, Universiti Teknologi Malaysia Kuala Lumpur. Her research interests include mobile and wireless communications, error control coding, relay networks, cooperative communications, Hybrid ARQ Cross Layer Design and iterative receiver.

Mohd Firdaus Mohd Noor is an academic staff of Mechanical Engineering Department in Polytechnic Banting Selangor. He received his Bachelor in Mechanical Engineering (Structure and Materials) in 2006 from Kolej Universiti Teknikal Kebangsaan Malaysia. He then pursued his Master in University Technology Malaysia in Engineering Design in 2017. He has been involved in the area of Materials Engineering and Engineering Design which focusing on material testing, designing and simulation including finite element analysis, computational fluid dynamics and structure analysis. 

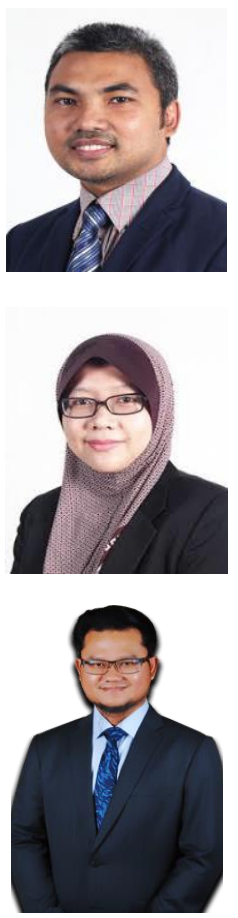

Sa'ardin Abdul Aziz is the academic staff of Razak Faculty of Technology and Informatics, Universiti Teknologi Malaysia Kuala Lumpur. He received a Diploma in Mechanical Engineering (Aeronautics) in 1995, Bachelor of Mechanical Engineering (Aeronautics) in 1998, and Master of Mechanical Engineering in 2002 from Universiti Teknologi Malaysia. He then obtained a PhD in Mechanical Engineering from the University of Glasgow, United Kingdom in 2012. He is involved in the field of ultrasonic metal forming, finite element analysis, finite element modelling, heat transfer, safety engineering, micro hydro turbine, ram pump and wind turbine.

Dr Nurul Aini Bani received her M.Eng degree in Electrical Engineering from University of Southampton, UK in 2006 where she received two academic awards for outstanding academic performance. She received her $\mathrm{PhD}$ degree in Electrical Engineering from Universiti Teknologi Malaysia (UTM). Her research interests include polymeric insulation material, space charge measurement, high voltage cable, renewable energy, rural technology and rehabilitation engineering. Her current work concentrates on developing low cost renewable energy system for rural and remote area, namely solar concentrator and saltwater battery.

Noorazizi Bin Mohd Samsuddin holds a Diploma in Mechanical Engineering from UTM, Malaysia, in 2000; Honours Degree in Mechanical Engineering from UTM, Malaysia in 2004; Master in Mechanical Engineering (Computational Fluid Dynamic) from UTM, Malaysia in 2009 and $\mathrm{PhD}$ in the field of Manufacturing Engineering (Biomedical Engineering) at UTeM, Malaysia in 2017. He has vast experience in Mechanical Engineering as an academic as well as professional management consultant in the field of Mechanical \& Electrical (M\&E), HVAC System and Manufacturing. His specialization are in the area of Design of Experiment (DOE), Response Surface Methodology (RSM), Machining (Medical Tools), and he has won many multiple awards in the Outside Innovation Project and internationally. He has recently won the Gold Medal Award together with two Special Awards from Poland and Russia in Geneva, Switzerland through OrthoDrill products. 